\title{
Martin Buber's Philosophy and Integral Ecology
}

\author{
Pavol Dancak ${ }^{1, *}$ \\ ${ }^{1}$ Department of Philosophy and Religious Studies, Greek-Catholic Theological Faculty, University of Presov, \\ Presov 08001, Slovak Republic \\ *Corresponding author.Email: pavol.dancak@unipo.sk
}

\begin{abstract}
Nowadays ecological issues gain momentum depending on the consumer use of technology on a global scale. Pope Francis argues that the destruction of the environment is a sin because the planet is transformed into a wasteland full of ruins and dirt cannot be a safe place for human life. The Bishop of Rome calls for an "integral ecology," which includes our vocation to solidarity with the poor, but also to care for the Earth. Our deep respect for the dignity of each person commands us to cultivate an environment of life where each of God's children prospers and unites with creation in celebration of our Creator. The aim of the article is to introduce the personalism of Martin Buber as a suitable contribution to solving current environmental problems. Martin Buber's philosophical and religious reflection states that human life develops in three spheres, in which the decisive role is played by the relationship to nature, the relationship to people and the relationship to a spiritual being whom we do not hear but we are responsible to.
\end{abstract}

Keywords: Person, Integral ecology, Dialog, Relationship.

\section{INTRODUCTION}

We are currently witnessing social movements that show that environmental problems are not just a matter for elite groups and movements, but that they are also affecting agriculture, industry and the economy. Ecological issues put a deep seal on philosophical and theological reflection. At first glance, this would seem to be a new trend, but a careful look at the history of thought shows us that the question of the relationship between man and the world, concern for the home - the oikos, has been the subject of human inquiry since time immemorial. What has changed significantly, however, is the urgency, which is highlighted by technical possibilities and globalization, but also by the unprecedented emphasis on the individual and his claims and rights. The consequences of the consumerist approach to the world are so significant that today we are talking about manmade ecological crisis. A culture based on the boundless increase of consumption contradicts and endangers itself, because it no longer leads to cultivation, but to documentable demolition in the form of deforestation, desertification, water mismanagement, soil erosion, air pollution, climate change, and general inability to rational utilization of ecosystems. Of course, the action elicits a reaction. The catastrophic environmental realities have also provoked efforts to limit, in fact prevent, the devastation of our common living space.

Popes of the twentieth century reflect the threat to the environment in their encyclicals and public speeches. Papal documents reject the instrumental use of nature, which is intended only to satisfy any human desire. An instrumental approach to the world is the result of a misunderstood place of man in the world. This understanding lack what existentialists have called "being in the world," i.e. the awareness of that man has been connected from the beginning with innumerable ties to other people, things, and nature. Accepting one's place in the world is the content of the integral ecology called for by Pope Francis. Martin Buber is one of the most influential thinkers of the 20th century, who warned against reductionist anthropologies. The common denominator of "integral ecology" and Buber's reflection on the dialogical character of human existence in the world is the effort of man to take his adequate position in the world.

In the article, we will first state that a person's interest in his own place in the world extends to the very foundations of our culture in Greek and 
biblical thought. Then we present some of the popes' statements on ecology and finally show that dialogue, as understood by Martin Buber, is a suitable tool for building relation that represents the prevention of environmental disaster.

\section{THE CONCERN ABOUT THE PLACE OF MAN IN THE WORLD - PART OF THE FOUNDATIONS OF OUR CULTURE}

In the ancient world we can find not only the claim of Protagoras that man is the measure of all things, but also a reflection of human life in the world. Homer clearly shows the situation of man in the Iliad when describing the bas-reliefs of the Achilles shield. Hephaestus represents the sky, the earth, the sea, the sun, and the full moon, but also the constellations. He also placed there a picture of two places and life events of the inhabitants. And around it all at the edge of the round shield flows the Ocean. The mood of the epic encourages humility against the gods and the order of the world - against the order which was disturbed by the abduction of the Spartan woman, the dispute between Agamemnon and Achilles, and every brutality and lie of war. The basic values of the community are given, determined from above, and each individual has a certain role in the determined system.

For the needs of my paper, I will use the Bible, which as the cornerstone of our culture shows the beauty of creation. The book of Genesis emphasizes that everything God has created is good. The sky, the earth, the stars, water, plants, animals, and man exist in relation to each other and represent a trace of creative power in nature. Therefore, the universe is a sacrament, a sign of the presence of God and the most beautiful shrine. Man was created in the image and likeness of God, and through his body from the clay of the earth he participates in the life of nature and nature is part of human life.

Man has been made king on earth from the beginning, to subdue the earth and enjoy the fruits. But the king is not here to oppress his subjects, but to make the sign of the Creator more pronounced in the world. In the second description of creation in the book of Genesis: "And the Lord God made man, and set him in the paradise of Eden, to work and keep him [Gen 2:15]. Man is called to take care of the earth and watch over it with love, so that it develops in accordance with the possibilities contained in it. Such care for the earth, which above all protects its spontaneous development, becomes for Christ a paradigm of the "culture" of God in human hearts: "With the Kingdom of God, it is as if one throws a seed into the earth; whether he sleeps or gets up, at night or during the day, the seed germinates and grows and he doesn't even know it. The earth yields a harvest of its own: first the stalk, then the ear, and finally the full grain in the class. And when the fruit is ripe, he shall bring forth a sickle, for the harvest is come" [Mk 4: 26-30].

The sower's parabola shows in a literary summary something that has been completely forgotten in "consumer" culture: respect for creation. God has respect for his own creation because he endowed it with his own creative power and made it independent. The beauty of nature and the beauty of man is above all the beauty of life, which is able to develop itself according to its own laws. In fact, the real culture is protection. Man protects what bears a sign of God's independence in its essence, sovereignty and power, and which is therefore a sacrament, but which is also fragile and requires care, full of respect and a sense of responsibility. Only then can we fully satisfy our needs, of which the need for selfless admiration of beauty is by no means in the last place. Therefore, the idea of protecting nature is an idea of harmony of relationships inspired by the spirit of the Bible. Nature conservation does not mean an escape from culture to nature, but a transition from a lower culture to a higher culture $[1 ; \mathrm{P} .53]$.

\section{INTEGRAL ECOLOGY}

Since the middle of the twentieth century, we have been living in a world in a situation in which the nature is no longer able to heal itself from manmade wounds. Ecology has transformed from the doctrine of the local coexistence of organisms into a consideration of the general imbalance in man's relationship with the Earth. Disruption of this balance threatens the very existence of humanity. Today, we cannot reduce ecology just to a better human survival. Ecology has a moral and integral dimension, it is a challenge to save the essential determination of everything that is a partner of human earthly existence. The popes' speeches place a clear emphasis on the fact that the ecological approach carries fundamental general values.

At the turn of the millennium, Pope John Paul II writes in the encyclical "Centesimus annus": "Equally worrying is the ecological question which accompanies the problem of consumerism and which is closely connected to it. In his desire to 
have and to enjoy rather than to be and to grow, man consumes the resources of the earth and his own life in an excessive and disordered way. At the root of the senseless destruction of the natural environment lies an anthropological error, which unfortunately is widespread in our day. Man, who discovers his capacity to transform and in a certain sense create the world through his own work, forgets that this is always based on God's prior and original gift of the things that are. Man thinks that he can make arbitrary use of the earth, subjecting it without restraint to his will, as though it did not have its own requisites and a prior God-given purpose, which man can indeed develop but must not betray. Instead of carrying out his role as a cooperator with God in the work of creation, man sets himself up in place of God and thus ends up provoking a rebellion on the part of nature, which is more tyrannized than governed by him. ${ }^{76}$

In all this, one notes first the poverty or narrowness of man's outlook, motivated as he is by a desire to possess things rather than to relate them to the truth, and lacking that disinterested, unselfish and aesthetic attitude that is born of wonder in the presence of being and of the beauty which enables one to see in visible things the message of the invisible God who created them. In this regard, humanity today must be conscious of its duties and obligations towards future generations" [2; P. 37].

Similarly, Benedict XVI focuses on environmental issues in his speech in Australia: "Yet the views afforded of our planet from the air were truly wondrous. The sparkle of the Mediterranean, the grandeur of the north African desert, the lushness of Asia's forestation, the vastness of the Pacific Ocean, the horizon upon which the sun rose and set, and the majestic splendour of Australia's natural beauty which I have been able to enjoy these last couple of days; these all evoke a profound sense of awe. It is as though one catches glimpses of the Genesis creation story - light and darkness, the sun and the moon, the waters, the earth, and living creatures; all of which are "good" in God's eyes [cf. Gen 1:1 2:4]. [...] What do we discover? Perhaps reluctantly we come to acknowledge that there are also scars which mark the surface of our earth: erosion, deforestation, the squandering of the world's mineral and ocean resources in order to fuel an insatiable consumption. [...]My dear friends, God's creation is one and it is good. The concerns for nonviolence, sustainable development, justice and peace, and care for our environment are of vital importance for humanity. They cannot, however, be understood apart from a profound reflection upon the innate dignity of every human life from conception to natural death: a dignity conferred by God himself and thus inviolable [3].

At present, environmental issues are gaining momentum depending on the consumer use of technology on a global scale. Pope Francis perceives the intensity of the threat and claims that the destruction of the environment is a sin, as the planet transformed into a wasteland full of debris and dirt cannot be a safe place for human life. The Bishop of Rome calls for an "integral ecology," which includes our vocation to solidarity with the poor, but also to care for the Earth. Pope Francis, in an allusion to St. Francis of Assisi, says: "Everything is related, and we human beings are united as brothers and sisters on a wonderful pilgrimage, woven together by the love God has for each of his creatures and which also unites us in fond affection with brother sun, sister moon, brother river and mother earth" [4; No. 92].

Integral ecology is a key concept in chapter four of "Laudato si", Pope Francis' encyclical on the environment. It flows from his understanding that "everything is closely related" and that today's problems call for a vision capable of taking into account every aspect of the global crisis.

Relationships take place at the atomic and molecular level, between plants and animals, and among species in ecological networks and systems. For example, he points out, "We need only recall how ecosystems interact in dispersing carbon dioxide, purifying water, controlling illnesses and epidemics, forming soil, breaking down waste, and in many other ways which we overlook or simply do not know about. [4; No. 140]. "Nor can the "environment" be considered in isolation. "Nature cannot be regarded as something separate from ourselves or as a mere setting in which we live," writes the pope. "We are part of nature." [4; No. 139].

Pope Francis also calls for a "social ecology" that recognizes that "the health of a society's institutions has consequences for the environment and the quality of human life" [4; No. 142]. This includes the primary social group, the family, as well as wider local, national, and international communities. When these institutions are weakened, the result is injustice, violence, a loss of freedom, and a lack of respect for law - all of which have consequences for the environment. Pope Francis also argues that it is important to pay attention to "cultural ecology" in order to protect the cultural 
treasures of humanity. But "Culture is more than what we have inherited from the past; it is also, and above all, a living, dynamic and participatory present reality, which cannot be excluded as we rethink the relationship between human beings and the environment." [4; No. 143].

Pope Francis' encyclical letter Laudato si' not only points out acute problems of humanity but also delineates a way forward, part of which must necessarily be active listening within an honest dialogue of parties involved. Only an intentional, honest, and continuous dialogue of religious and secular entities of social discourse may bring about an adequate understanding of the contemporary state of human global community on local as well as international levels and, at the same time, a realization of the acute nature of our need to cultivate a new vision and ethos in line with "integral ecology" with the goal of sustainable development and life on Earth [5; P. 38].

Let us recall here the main theses and titles of subsections: Dialogue on the environment in the international community [4; P. 164-175], Dialogue for new national and local policies [4; P. 176-181], Dialogue and transparency in decision- making [4; P. 182-188], Politics and economy for human fulfilment [Francis 2015, 189-198], Religions in dialogue with science [4; P. 199-201]. Dialogue, dialogue, dialogue - the most underrated and overlooked idea of Laudato si'.

How to bring it to our ecological debate? For Christian ecologists, it is crucial to bear witness to God's love for all people by defending the dignity of the human person at every stage of his life, promoting peace and the common good, and striving to jointly build a just and humane society in which no one feels excluded or marginalized [6; P. 25]. We can summarize that, popes see the fundamental problem of ecological failures in anthropology, in which the perception of the dialogical nature of man is absent.

\section{MARTIN BUBER - INSPIRATION FOR ECOLOGY}

In the last part of the article, I will present the personalism of Martin Buber as a valuable contribution to solving current environmental problems. Martin Buber's dialogic personalism has a similar integral character to the ecological challenges of the popes.

Personalism arose in response to the crisis in Western society, manifested in the form of economic crisis in the 1920s and 1930s. The crisis, as a symptom of deeper problems stemming from on the depersonalizing acts of man, did not remain without monstrous consequences. Later developments showed that the crisis was primarily a value crisis. The arrogant penetration of dehumanizing tendencies into human thought and into practical life required the alignment of all forces recognizing that the ultimate goal of all efforts is human. Martin Buber's philosophical and religious reflection states that human life develops in three spheres, in which the decisive role is played by the relationship to nature, the relationship to people and the relationship to a spiritual being whom we do not hear but to whom we are responsible.

Personalism exists in many different versions, and such as that represented by the dialogical philosophy of Martin Buber, pay less attention to the difference between persons and non-persons and underscore instead the way one relates to all of reality. Buber separates the way of dealing with other realities into two, which he terms "I-Thou" and "I-It" relationships, the first reflecting a fundamental openness to the reality of the other and the latter reflecting an objectivization and subordination of the other to oneself.

In Buber`s the most important work entitled "I and Thou" we can read that the world is twofold for man in accordance with his twofold attitude. The attitude of man is twofold in accordance with the two basic words he can speak. The basic words are not single words but word pairs. One basic word is the word pair I-Thou. The other basic word is the word pair I-It [7; P. 46]. According to Buber "IThou" relation does not always have to refer to an interpersonal relation. We involve others either as an It, forming an I-It primary word, or as a Thou, forming the I-Thou primary word. He was inclined to accept a dialogue relation towards such an object as a tree with which we can become friends. ${ }^{1}$ This remark raises the question, especially in the ecological context, whether it is not necessary for the I-Thou relation to accept, for example, a concept of the world where every living and nonliving entity has a soul or consciousness, that is, accepting a certain form of animism [9; P. 55-56]. Buber anticipates this problem in a passage that compares the relationship of I-Thou to the tree:

1. Yet whereas some personalists would assert that such an I-Thou relationship is the only appropriate way of dealing with persons, and the I-It relationship the only appropriate way of dealing with things [8]. 
"The tree will have a consciousness, then, similar to our own?" [10; P. 8] and adds that he has no experience that would confirm this. He continues: "I encounter no soul or dryad of the tree, but the tree itself. [10; P. 8]. Buber clearly rejects any form of animism in connection with the I-Thou relation, he rejects the necessity of the presence of the soul on the opposite side in order for the relationship to be realized. Thus, in the relation between I and Thou, it is an encounter with the opposite as it is, regardless of its ontological structure, regardless of whether it is a conscious subject or not, whether it is able to pronounce the basic word or not $[11$; P. 573].

Buber does not reduce the I-Thou relationship between man and nature to a mere metaphor. He wrote in the abovementioned passage on man's relationship to the tree: "Let no attempt be made to sap the strength from the meaning of the relation: relation is mutual" [10; P. 8].

Buber presents the I-Thou relation as the ideal for the human person's dealing with all reality, personal and non-personal alike. And though this IThou relation will take on different characteristics according to the sphere in which the relation arises [nature, men, spiritual beings], for Buber the fundamental difference lies within the human person himself and in the attitude with which he engages reality [8].

Dialogue plays a central role in finding an adequate place for a person in the world. Dialogue assumes a conversation and a necessity to listen to the other. A real discovery of a true "I" lies in the encounter with "Thou", and "I" does not exist without a relation with "Thou". The "I-Thou" relation is a relation to another man, to a person but also to God, whereas "I-It" is a relation to an object, to the world, to everything that surrounds us and is not a person. Man becomes "I" in contact with "Thou", in relation with "Thou": "I become "I" through my relation with Thou" [12; P. 47]. Man can enter into a monologue relation with reality "IIt", in which there is a lack of a dialogue, or in a dialogue relation "I-Thou". Whatever happens between people is a sphere of mutual "confrontation" and constitutes the foundations of dialogism. A dialogue should be built not based on searching for unity and common truths but on axiological experience of otherness. Encounter and dialogue constitute a starting point and principle of any philosophizing [7; P. 44] but the dialogue does not 'create' what is right, rather it points to what is right now, in the situation.
If we relate purely in the I-It mode then we are inauthentically fleeing the wholeness of our Being, and the wholeness of the Other's Being. If we relate in the I-Thou mode [which includes our It-self] then we act authentically, with compassion and inclusion, and through dialogue with the Other we can agree upon or discover the correct ethical behaviour which we should follow [13; P. 93-94].

Hasidism played a very important role in the thinking of M. Buber [14; P. 127]. One of the central principles that Buber adopted from Hasidism and incorporated into his philosophy is the religious concept of "devekut". According to G. Scholem, it is an "intimate communion with God" [15; P. 390]. Buber agreed that such a sacred commune could be established in the daily mundaneness of human life. He rejected the idea that the only place to meet God was a ritual, a ceremony, or a mystical state. He emphasized God's connection with the profane world, and thus the possibility of achieving it. Based on the doctrine of cimcum M. Buber_claimed: "In every sphere in its own way, through each process of becoming that is present to us, we look out toward the fringe of the eternal Thou; in each we are aware of a breath from the eternal Thou; in each Thou we address the eternal Thou. Every sphere is compassed in the external Thou, but it is not compassed in them" [10; P. 101] $]^{2}$.

Hasidic teaching says that one should not deal with oneself. Of course, every person knows himself, purifies himself, perfects himself, but not for himself, not for his earthly happiness, nor for the sake of heavenly bliss, but for the works that one has to do in the world of God. One should forget oneself and keep the world in mind. ${ }^{3}$ Every spiritual self-improvement leads one to take responsibility and to respond positively to God's call. After all, God has a plan for each person, he has given him a certain task, the fulfillment of which is of benefit to the whole world.

In the context of $\mathrm{M}$. Buber's reflections on ecology and philosophy, it is also necessary to

2. "In jeder Sphäre, in jedem Beziehungsakt, durch jedes uns gegenwärtig Werdende blicken wir an den Saum des ewigen Du hin, aus jedem vernehmen wir ein Wehen von ihm, in jedem Dur eden wir das ewige an, in jeder Sphäre nach ihrer Weise. Alle Sphren sind in ihm beschlossen, es inkeiner" [16; P. 147].

3. "Wohl soll jede sicher kennen, sich läutern, sich vollenden, aber nicht um ihrer selber willen, wie nicht um ihres irdischen Glücks, so auch nicht um ihrer himmlischen Seligkeit willen sondern um des Werks willen, das sie ander Welt Gottes vollbringen soll. Man soll sich vergessen und die Welt im Sinn haben" [17; P. 733]; [18; P. 38]. 
mention the Hasidic teaching on humility, shiflut [Hebrew ענווה], which Buber developed in his collection essay "Vom Leben der Chassidim". Man is impurely humble when he humiliates himself too much and forgets the power of his words, which have the power to bless the world. True humility lies in feeling others as oneself and oneself in others ${ }^{4}$, so the world around him is not indifferent to him. Such a person perceives himself as part of a collective, without which the whole would not be possible. At the same time, however, he knows that he, as one part, has responsibility not only for himself but also for the other parts.

\section{CONCLUSION}

Martin Buber represents a significant group of philosophers reflecting atrophy of social life at that time. He emphasizes that the basis of human existence does not lie in an individual nor in the entire society, but between two people, which means the basis of human existence is dialogue. Buber believed that life is essentially a complex of interpersonal relationships, and one is able to build a relationship in the fundamental spheres of one's existence. The basis of life is love, which directs one human being to other one. Man is unique and necessarily perceives the counterpart as himself, and needs to feel himself in the others. The element of dialogue is the essence of anthropology [19]. Human humility, which appears in dialog, could certainly be an antidote to our arrogant sense of ownership of all creatures [20], the land, the air, the water!

The role of integrative dialogue in the search for ecological balance is emphasized by Pope Francis in the encyclical Laudato si': "Environmental education has broadened its goals. Whereas in the beginning it was mainly centred on scientific information, consciousness-raising and the prevention of environmental risks, it tends now to include a critique of the "myths" of a modernity grounded in a utilitarian mindset [individualism, unlimited progress, competition, consumerism, the unregulated market]. It seeks also to restore the various levels of ecological equilibrium, establishing harmony within ourselves, with others, with nature and other living creatures, and with God. Environmental education should facilitate making the leap towards the transcendent which gives ecological ethics its deepest meaning. It needs educators capable of developing an ethics of

\footnotetext{
4. "die anderewiesichfühlt und sich in den andern" [17; P. 40].
}

ecology, and helping people, through effective pedagogy, to grow in solidarity, responsibility and compassionate care" [4; No. 210].

\section{AUTHORS' CONTRIBUTIONS}

This paper is independently completed by Pavol Dancak, including conceptualization, methodology, investigation, writing - original draft preparation, writing — review, and editing, resources, and $\mathrm{r}$ eferences

\section{REFERENCES}

[1] Pawlikowski, J. G.: Kultura a natura. - O lice ziemi. Warszawa, 1938.

[2] John Paul II: Centesimus annus https://www.vatican.va/content/john-paul-ii/ en/encyclicals/ documents/hfjpiienc01051991centesimus-annus.html [Accessed 12.04. 2020].

[3] Benedict XVI: Welcoming celebration by the young people address of his holiness Benedict XVI. https://www.vatican.va/content/benedictxvi/en/speeches/2008/july/documents /hfbenxvispe20080717barangaroo.html [Accessed 12.04.2020].

[4] Francis: Laudato si', https://www.vatican.va/content/francesco/en/e ncyclicals/documents/ papafrancesco20150524enciclica-laudato-si.pdf [Accessed 12.04.2020].

[5] Valčo, M.: Základné etické postoje v živote osoby, komunity a spoločnosti v kontexte encykliky Laudato si' pápeža Františka, RaN, roč. 19, č. 1, 2016, s. 37-48.

[6] Jaromi, S.: Dialogical and Mediatory Potential of an Integral Ecology. Studia Ecologiae et Bioethicae, 2020, 18, 1: 23-30

[7] Górzna, S.: Martin Buber father of the philosophy of dialogue. European Journal of Science and Theology, October 2014, Vol.10, No.5, p. 45-53.

[8] Williams, T. D. and Bengtsson J. O., "Personalism", The Stanford Encyclopedia of Philosophy [Spring 2020 Edition], Edward N. Zalta [ed.], URL = $<$ https://plato.stanford.edu/archives/spr2020/e ntries/personalism/>. 
[9] Hartshorne, CH.: Martin Buber's Metaphysics. In: Friedman, M. - Schlipp, P. A. [eds.]: The philosophy of Martin Buber. Transl. M. Friedman, La Salle/Illinois: Open Court, 1967, p. 49-68.

[10] Buber, M.: I and Thou. - Edinburgh: T. \& T. Clark 38 George Street, 1937.

[11] Bizoň, M.: On so Called "Mutuality" and IThou Relationship in Martin Buber. Filozofia, Vol. 69, 2014, No 7, p. 569 - 580.

[12] Kłoczowski, J.A.: Filozofia dialogu. - Poznań: W Drodze, 2005.

[13] Fairweather, R. E. [2013] Martin Buber's ecophenomenology: unturned ground in environmental ethics. MPhil[R] thesis, University of Glasgow. http://theses.gla.ac.uk/4104/1/ 2013FairweatherMPhil.pdf [Accessed 12.04.2020].

[14] Baloghová B.: Náboženský kontext filozofie Martina Bubera. - Prešov: PU GTF, 2019.

[15] Scholem, G.: Devecut, or Communion with God. In: The Messianic idea in Judaism. New York : Schoken Books, 1971.

[16] Buber, M.: Ich und Du. - Werke. Erster Band. Schriftenzum Philosophie. Heidelberg : Kösel \& Lambert Schneider, 1962.

[17] Buber, M.: Vom Leben der Chassidim. Werke. Dritter Band. Schriftenzum Chassidismus. Heidelberg : Kösel \& Lambert Schneider, 1963.

[18] Buber, M.: Život chasidů. - Praha: Arbor vitae, 1994.

[19] Chistyakova, Olga V. 2019. Religious Anthropology of Eastern (Greek-Byzantine) Patristics // European Journal of Science and Theology, vol. 15, no. 6. Pp. 145-155.

[20] Chistyakov Denis I. Nationalism in the Contemporary World: Theoretical Approaches and Empirical Implementation // Proceedings of the 20016 International Conference on Contemporary Education, Social Sciences and Humanities (ICCESSH 2016). Pp. 627-631. 